$$
-
$$


This page intentionally left blank 


\section{THE TEN \\ COMMANDMENTS}

A Short History of an Ancient Text

Michael Coogan

Yale UNIVERSITY PRESS

New Haven \& London 
Published with assistance from the Louis Stern Memorial Fund.

Copyright ( 2014 by Yale University.

All rights reserved.

This book may not be reproduced, in whole or in part, including illustrations, in any form (beyond that copying permitted by Sections 107 and I08 of the U.S. Copyright Law and except by reviewers for the public press), without written permission from the publishers.

Yale University Press books may be purchased in quantity for educational, business, or promotional use. For information, please e-mail sales.press@yale.edu (U.S. office) or sales@yaleup.co.uk (U.K. office).

Designed by James J. Johnson.

Set in Stemple Garamond type by Newgen North America, Inc. Printed in the United States of America.

\section{Library of Congress Cataloging-in-Publication Data}

Coogan, Michael David.

The ten commandments : a short history of an ancient text / Michael Coogan.

pages $\mathrm{cm}$

Includes bibliographical references and index.

ISBN: 978-0-300-I787 I-5 (cloth : alk. paper) I. Ten commandments-

Criticism, interpretation, etc. I. Title.

BSI 285.52 .6662014

$222^{\prime} .1606-\mathrm{dc} 23$

2013046737

A catalogue record for this book is available from the British Library.

This paper meets the requirements of ANSI/NISO Z39.48-I 992

(Permanence of Paper).

$1098765432 \mathrm{I}$ 
For Margaret Coogan and Elizabeth Lueke with love 
This page intentionally left blank 